Iranian Journal of Breast Diseases. 2021; 14(2):4-15.
Original Article

\section{The Effect of 12 Weeks of Interval and Continuous Training on Serum Levels of Interleukin-17 and Interleukin-10 in Postmenopausal Breast Cancer Survivors: A Clinical Trial}

\author{
Pournemati $\mathbf{P}^{1^{*}}$, Hooshmand Moghadam $\mathrm{B}^{1}$ \\ ${ }^{1}$ Department of Exercise Physiology, Faculty of Physical Education and Sport \\ Sciences, University of Tehran, Tehran, Iran
}

Receive: $16 / 2 / 2021$

Accepted: $24 / 4 / 2021$

"Corresponding Author: Pournemati@ut.ac.ir

Ethics Approval: IR.SSRI.REC.1398.055

\begin{abstract}
Introduction: Breast cancer is one of the inflammatory diseases, and physical inactivity is one of the risk factors. It has been suggested that exercise training can improve breast cancer outcomes by modulating inflammation. The aim of this study was to determine the effect of 12 weeks of high-intensity interval training and moderate- intensity continuous training on serum levels of IL-17 and IL-10 in breast cancer survivors.
\end{abstract}

Methods: In this quasi-experimental study, 45 postmenopausal women (age:57.25 \pm 3.91 ) who after the termination of breast cancer treatments, were randomly divided into three groups of 15 individuals each: (1) a high-intensity interval training (HIIT) group, (2) a moderate-intensity continuous training (MOD) group, and (3) a control group. HIIT and MOD were performed for 12 weeks, three days a week, using a cycle ergometer. Body composition and biochemical indices were evaluated 48 hours before and after the interventions. Data were analyzed using one- way ANOVA and the Tukey post hoc test at a significance level of 0.05 .

Results: The results showed that 12 weeks of HIIT and MOD significantly decreased IL-17 $(\mathrm{P}<0.001$ and $\mathrm{P}=0.004$, respectively) and significantly increased $\mathrm{IL}-10 \quad(\mathrm{P}=0.005, \mathrm{P}=0.027$, respectively $)$. However, a significant difference $(\mathrm{P}=0.004)$ was observed between the training group and the control group only in the levels of IL-17. In addition, no significant difference was observed between the two training groups in IL-17 or IL-10 ( $\mathrm{P}>0.05)$.

Conclusion: It seems that HIIT and MOD can be incorporated in breast cancer treatment plans as effective strategies for modulating inflammatory and anti-inflammatory factors.

Keywords: Interval Training, Continuous Training, Interleukin-17, Interleukin-10, Breast Cancer 


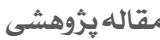

بروسى اثر IY هفته تمرين تناوبى و تداومى بر مقادير سرمى اينتر لوكين - V| و اينترلوكين - -1 در زنان يائسه مبتلا به سرطان بستان: يك مطالعه كار آزمايى بالينى

يريسا يورنعمتى "*، بابك هوشمند مقدم' احروه فيزيولوزى ورزشى، دانشكده تربيت بدنى و علوم ورزشى، دانشگاه تهران، تهران، ايران
فصلنامه بيمارى هاى يستان ايران

$1 \varepsilon \cdots ! 1 \varepsilon(r): \varepsilon-10$

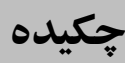

مقدمه: سرطان بستان از جمله بيمارىهاى التهابى است كه بـىتحركى از عوامل بروز آن

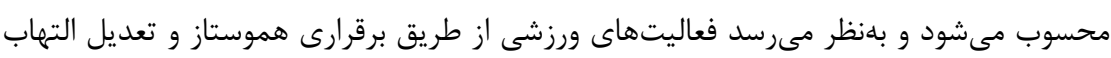

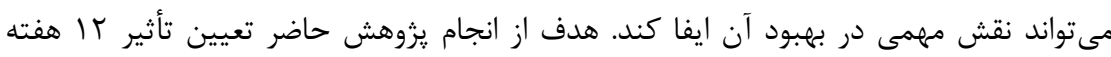

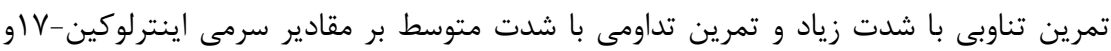

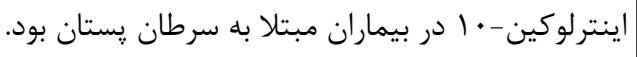

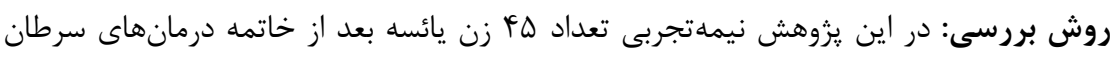

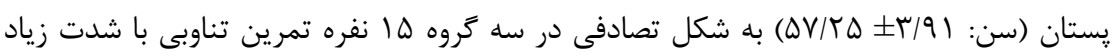

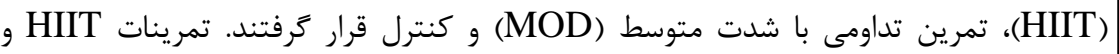
MOD

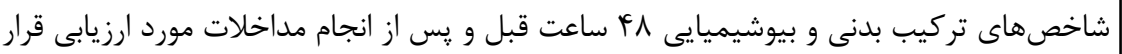

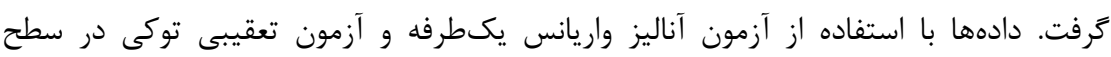

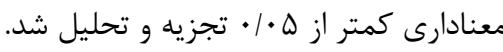

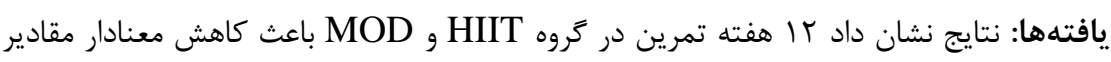

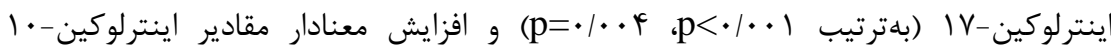

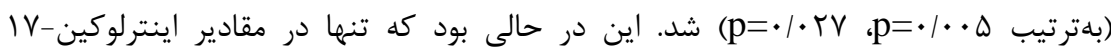

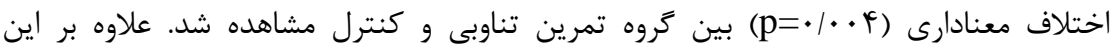

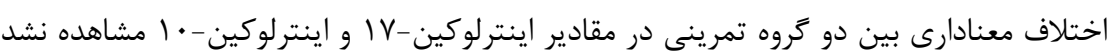
$(\mathrm{P}>\cdot / \cdot \Delta)$ نتيجه كيرى: بهنظر مىرسد انجام تمرينات تناوبى با شدت زياد و تمرينات تداومى با شدت

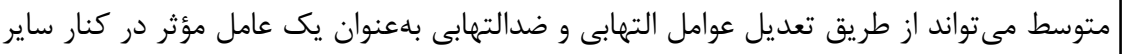

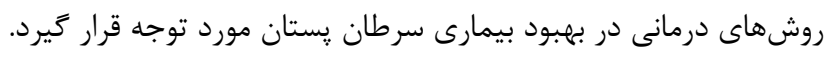
|وازههاى كليدى: تمرين تناوبى، تمرين تداومى، اينترلوكين-V|، اينترلوكين-• إ، سرطان يستان

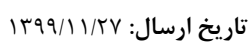

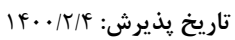

" نويسنده مسئول: Pournemati@ut.ac.ir 
دليل آثار ضدآنزيوزنزى مىتواند رشد و گسترش تومور را

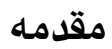

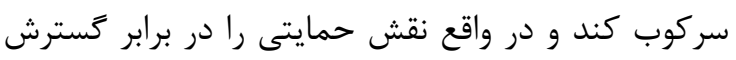

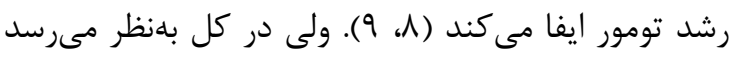

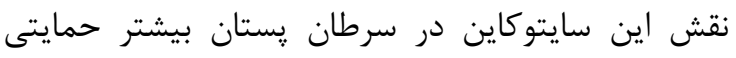

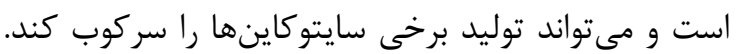

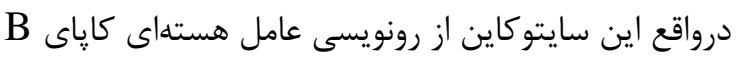

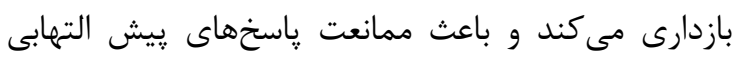

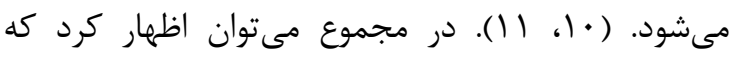

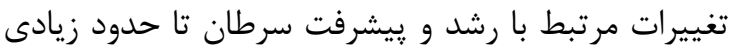

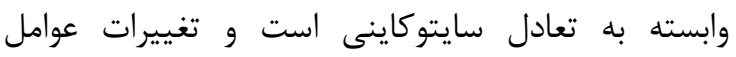

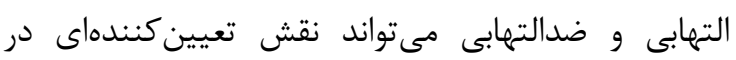
ييشرفت و كسترش سرطان داشته باشد (r) (I).

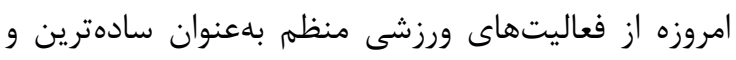
كمهزينهترين روش براى ييشگيرى از بيمارىهاى التهابى إنى

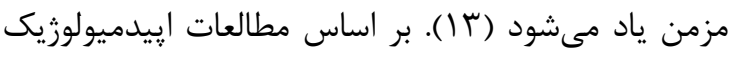

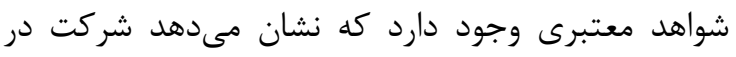

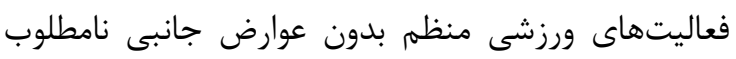

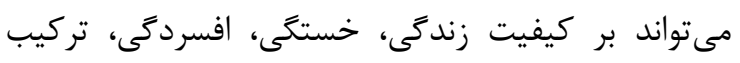

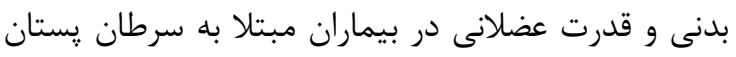

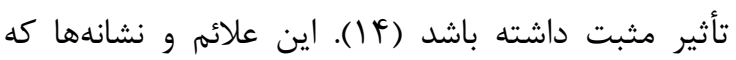

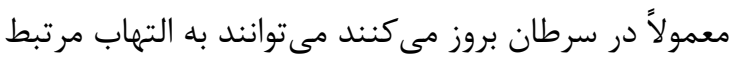

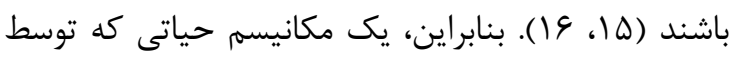

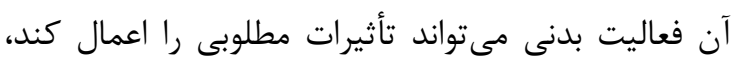
توانايى آن در كاهش التهاب مزمن است (Y) (1).

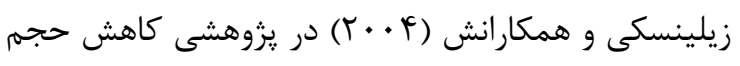

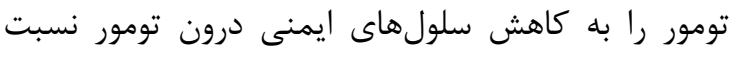

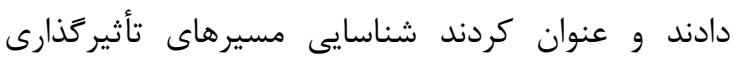
فعاليت بدنى بر تومورهاى سرطانى، از جمله التهاب يا مهار

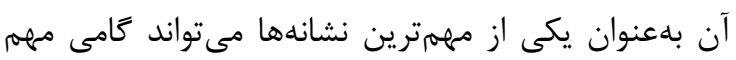

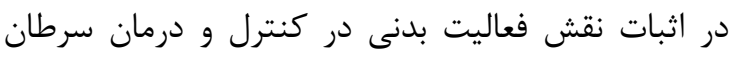

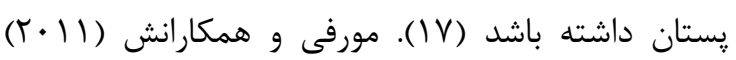

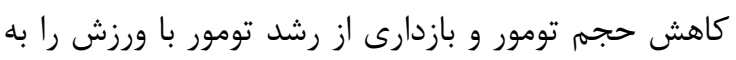

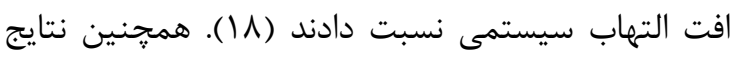

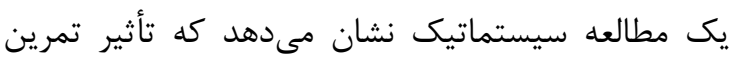
ورزشى بر واسطههاى مربوط به تومور، مانند سايتوكينها،

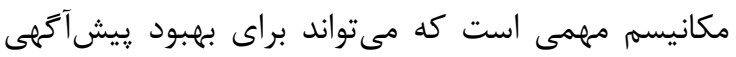

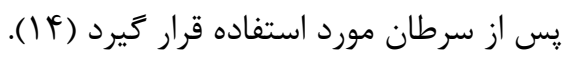

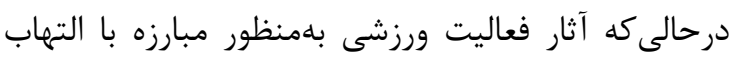
ناشى از سرطان و اثرات نامطلوب آن تا حدودى بيانشها

سرطان پِّتان شايعترين نوع سرطان در بين زنان است

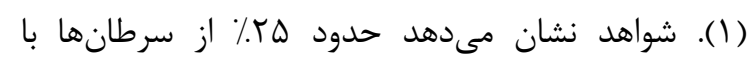
التهاب مزمن ناشى از عفونت يا حالتهاى التهابى با منشأ

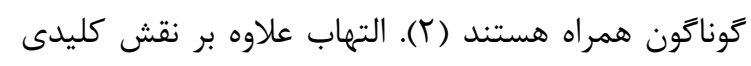
كه در توسعه تومور در سرطان يستان ايفا مى كند،

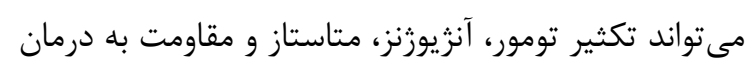

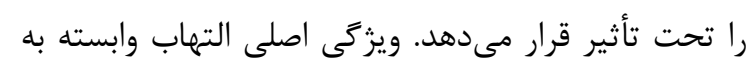
سرطان شامل نفوذ لكوسيتها، توليد سيتوكينها، تغيير

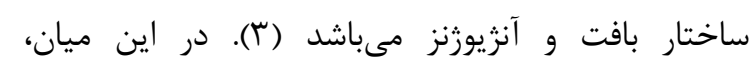

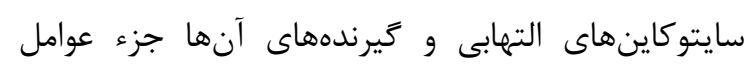

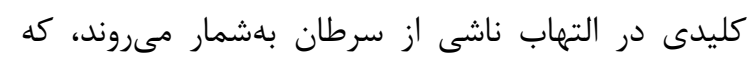

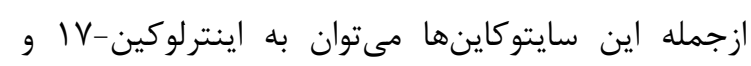

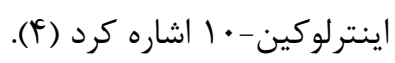

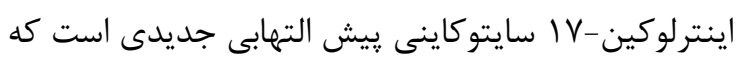

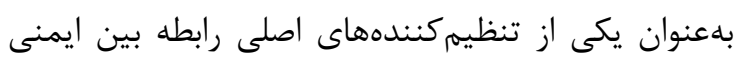

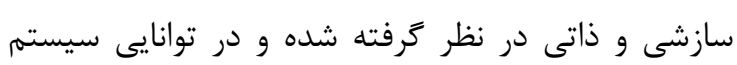

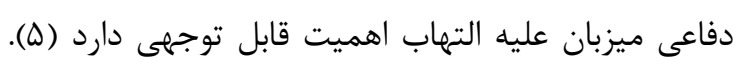

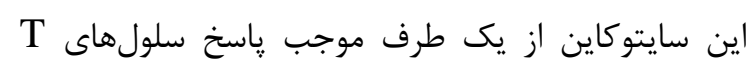

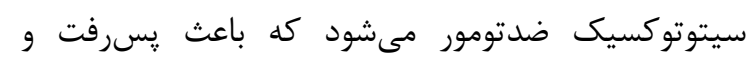
كاهش رشد تومور شده و از طرف ديكر با تسهيل فرايند ركزايى و خارج كردن سلولهاى تومورى از مركز اوليه

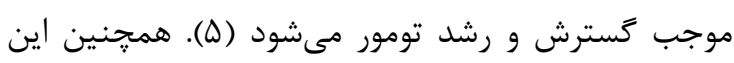

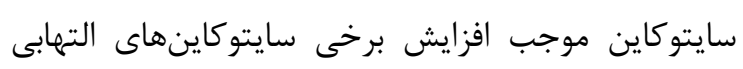

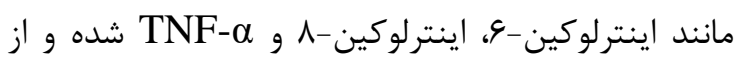

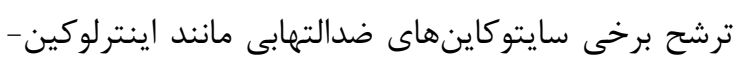

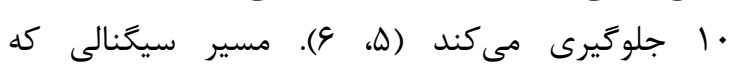

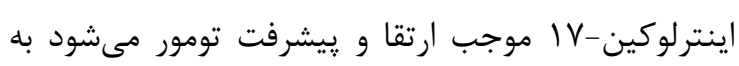
تحريك بيان STAT3 برمى كردد. بهعلاوه اين سايتوكاين

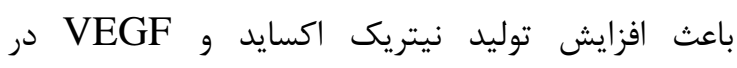

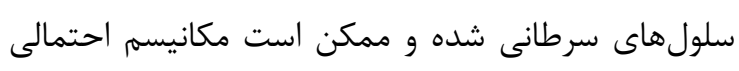

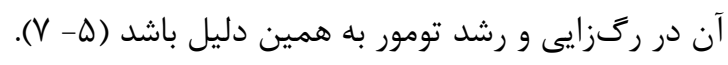

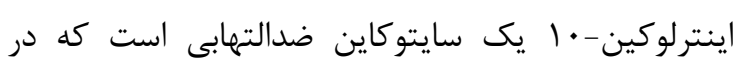

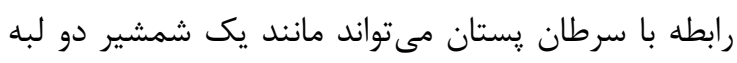

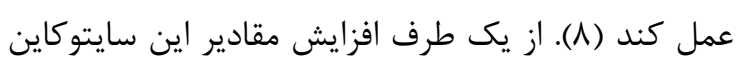

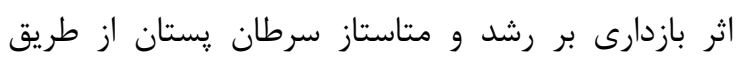
فعال سازى لنفوسيتهاى T سيتوتوكسيك دارد و مو مى تواند

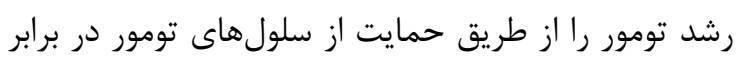

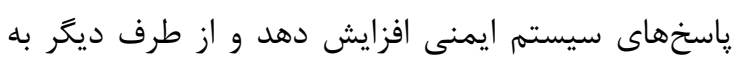




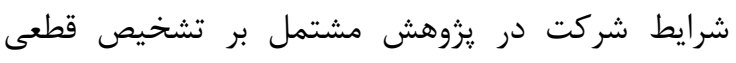

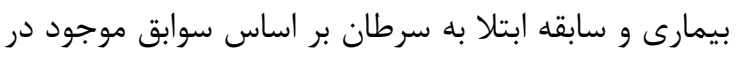

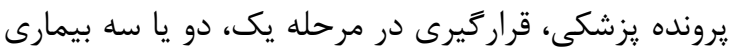

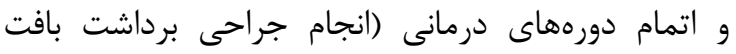

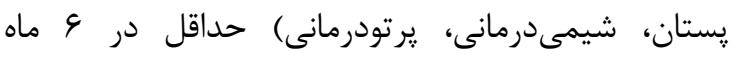

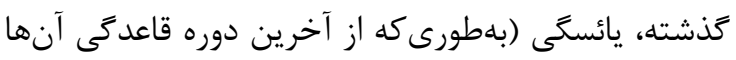

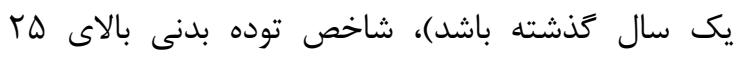

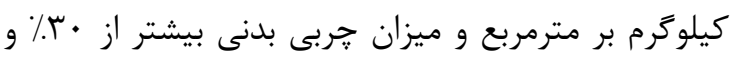

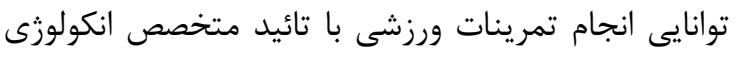
و متخصص قلب و عروق بود. همجنين معيارهاى خروج در

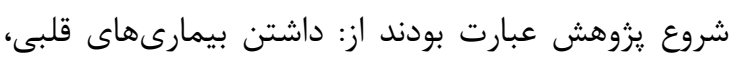

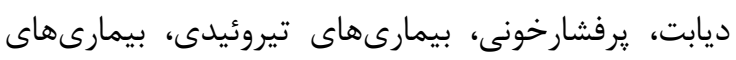

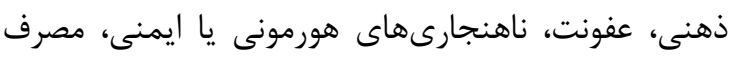

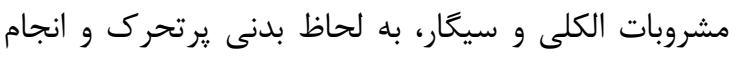

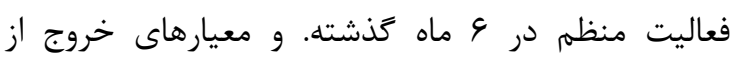

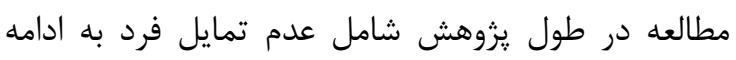

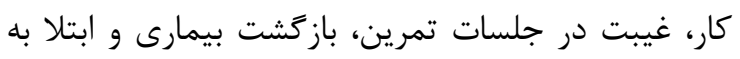
ديغر بيمارىها طى دوره مداخله بود.

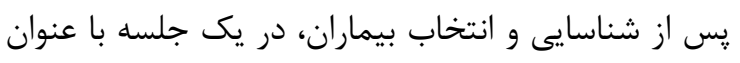

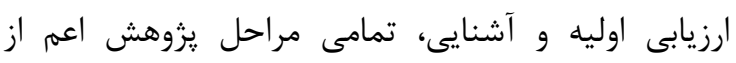

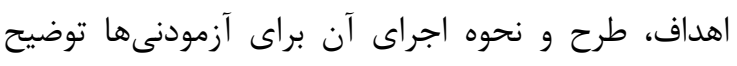

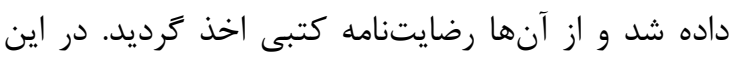

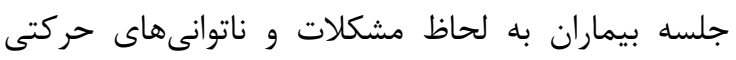
اندامها و وضعيت قلبى و تنفسى توسط فرد متخصص بله

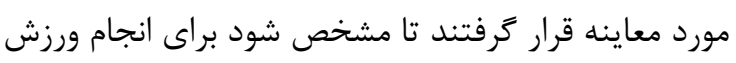

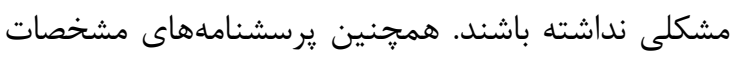

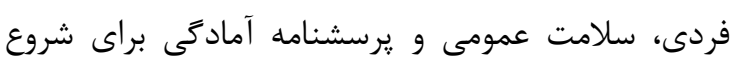

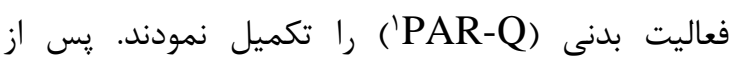

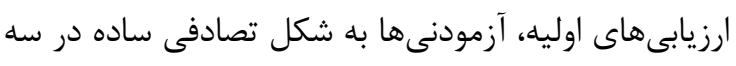

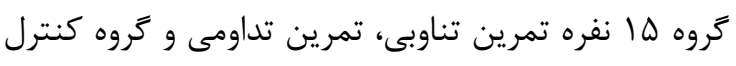

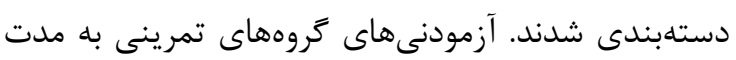

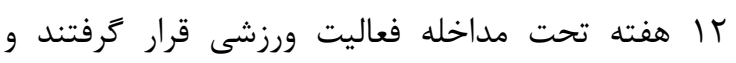

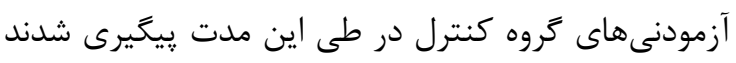

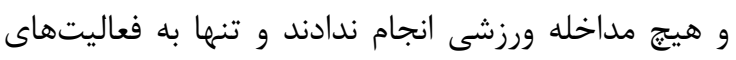
روزمره و مراقبتهاى درمانى رايج خود ادامه دادند. تمامى وردي

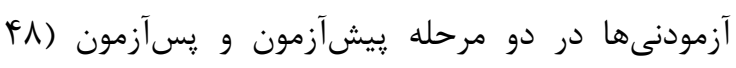

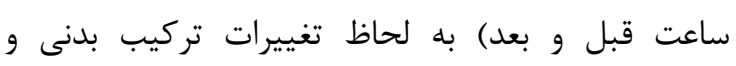

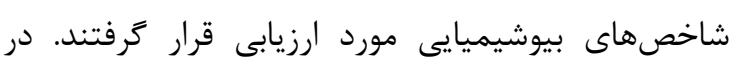

${ }^{1}$ Physical Activity Readiness - Questionnaire
است، با اينحال، مقدار حجم، شدت، تكرار و نوع فعاليت

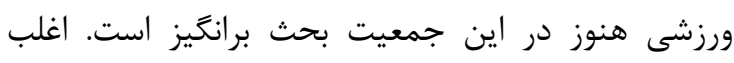

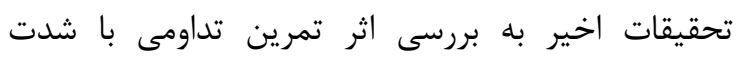

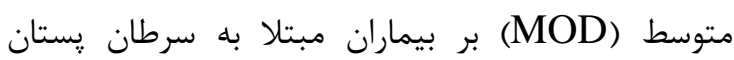

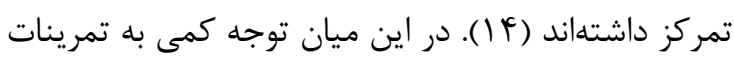
تناوبى و با شدت بالا شده است. امروزه استفاده از تمرينات

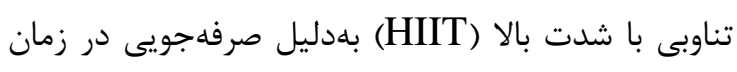

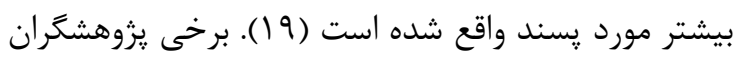

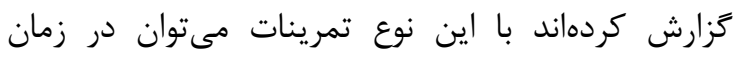

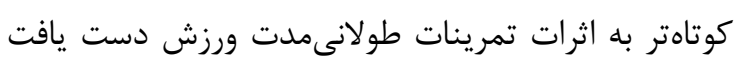

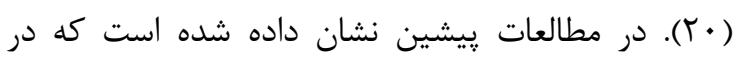

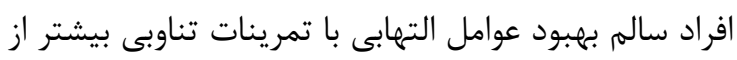

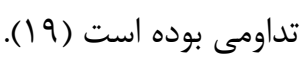
با توجه به بحثبرانخيز بودن نوع شيوههاى تمرينى مناسب (19) بودي

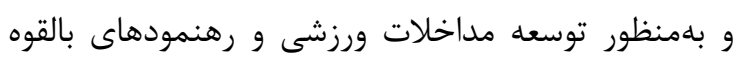

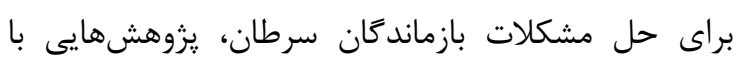

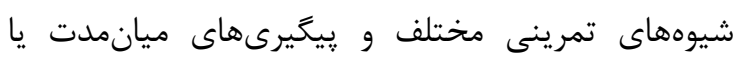

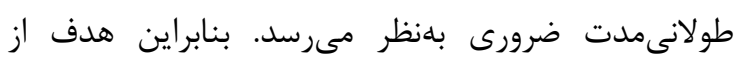

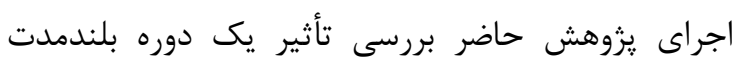

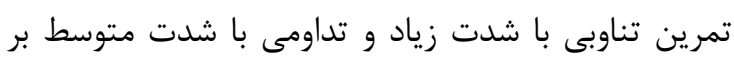

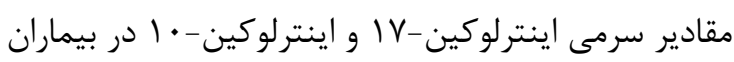
مبتلا به سرطان يستان بود.

\section{مواد و روشها}

تمام جنبههاى اين مطالعه مطابق با اصول اساسى

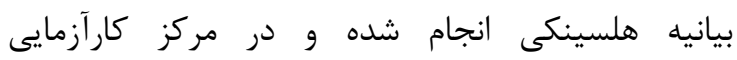

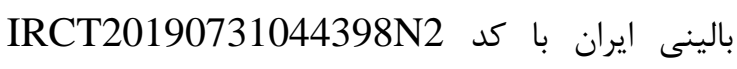

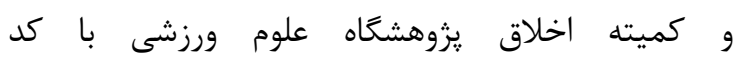
IR.SSRI.REC.1398.055 ثبت شد. يزوهش حاض كاض از نوع كاربردى و به روش نيمه تجربى بود كه در دو كروه

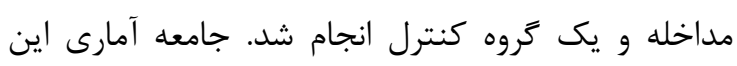

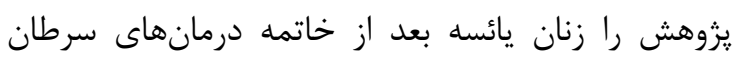

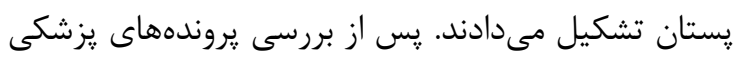

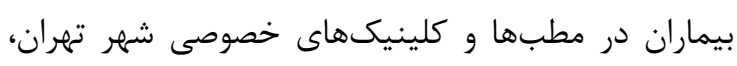

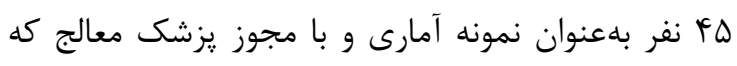

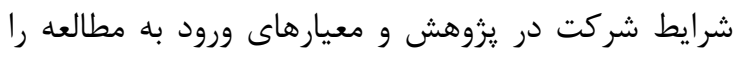

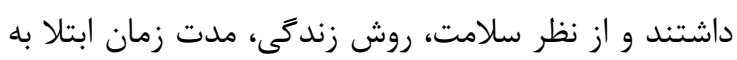

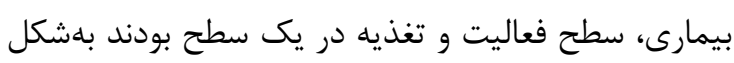
در دسترس و داوطلبانه انتخاب شدند. 
مىرساندند. ميزان ضربان قلب و RPE در انتهاى هر

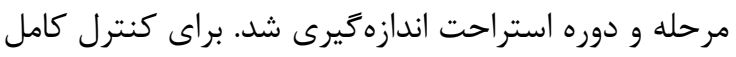

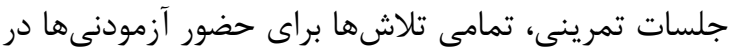

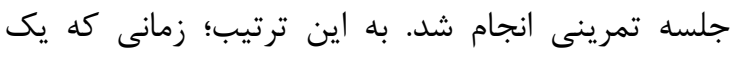

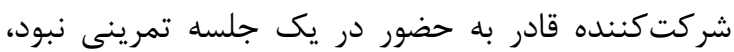
جلسه تمرينى بلافاصله روز بعد انجام مى شيد.

سنجش تركيب بدن براى اندازمخيرى شاخص هاى تركيب بدنى بدنى در هر مرحله،

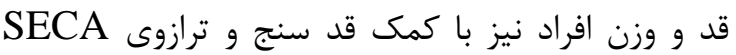
(ساخت كشور آلمان) اندازمكيرى شد. شاخص توده

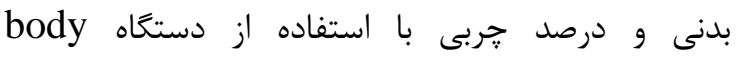
Sاخت composition analysis

$$
\text { سنجش مره جنغير ها بيوشيميام شديى. }
$$

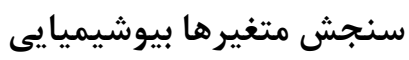

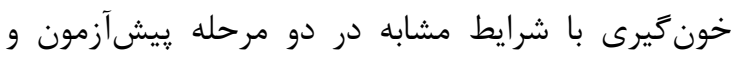

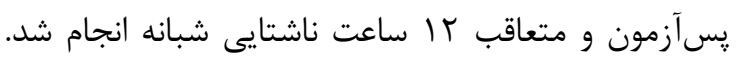

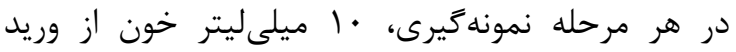

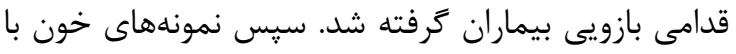

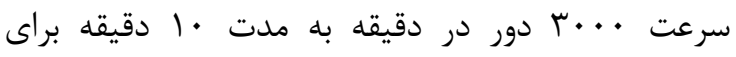
جداسازى سرم سانتريفوز شد و سرم بلهدست آمده در در در درد دماى •^ג- درجه سانتى

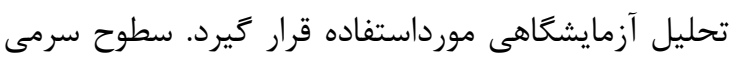

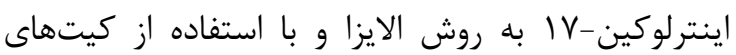
تحقيقاتى مخصوص نمونهاى انسانى (شركت R\&D

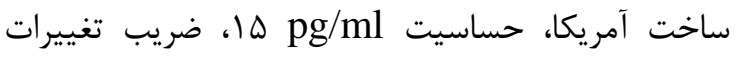

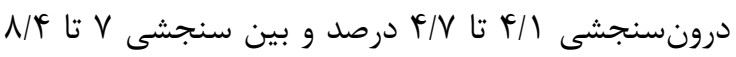

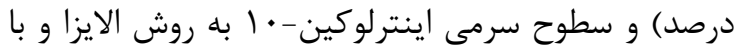

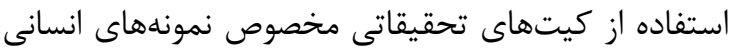
(شركت R\&D ساخت آمريكا، حساسيت

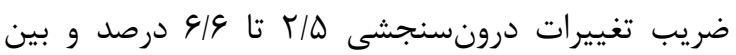
سنجشى ه/ه تا و/9 درصد) اندازهخيرى شد. آناليز آمارى

يس از بررسى طبيعى بودن توزيع دادهها با استفاده از

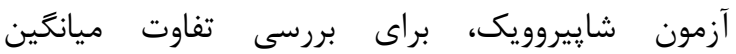
درونكروهى از روش آمارى تى همبسته و بلهمنظوري

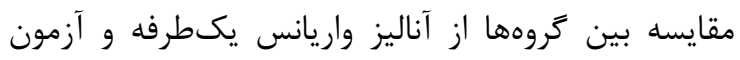
تعقيبى توكى استفاده شد. دادهها با استفاده از نرمافزار إنسار آمارى SPSS نسخه Tr و و سطح معنىدارى براى انجام محاسبهها ه • P P د نظر كرفته شد.
طول يزوهش از گروه تناوبى و تداومى دو نفر و از تروه كنترل يك نفر به دليل برخى مشكلات شخصى از ادامه

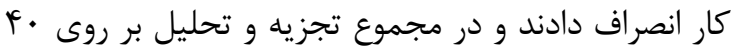

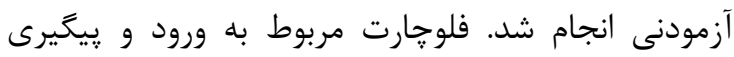
آزمودنىها در شكل ا قابل مشاهده است.

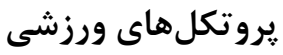
برنامههاى تمرينى با توجه به رهنمودهاى كالج ورنى ورزشى

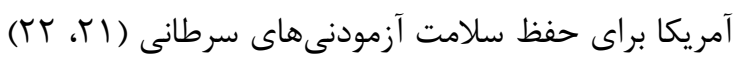

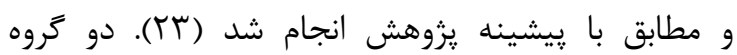
تمرين تناوبى با شدت زياد و تمرين تداومى با شدت

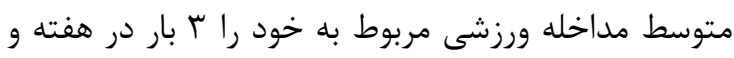

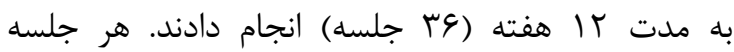
تمرينى با استفاده از دوجرخه كارسنج ( Monark 894E

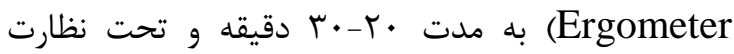

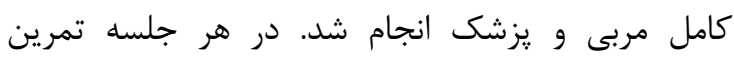
اطلاعات ضربان قلب آزمودنىها (بهوسيله ضربان سنجيلار ساخت فنلاند) و ميزان درك فنار تمرين (بهوسيله

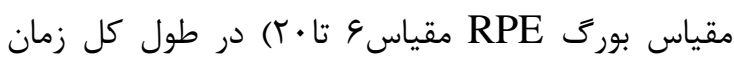
پايش و بلهصورت مرتب ثبت شد. كروه تمرين تداومى در ابتدا و انتهاى هر جلسه به ه دقيقه كرم كردن و سرد

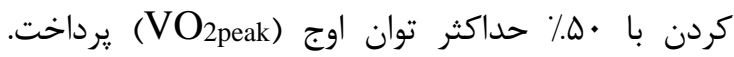

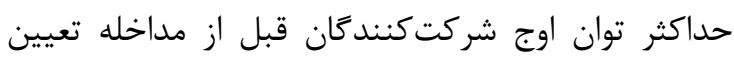
شد. تمرين اصلى در اين گروه پدال زدن با ههـ٪ از حداكثر

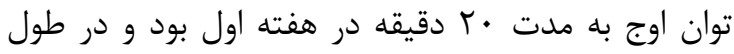
دوره (T) هفته) تعديل شد تا اطمينان حاصل شود كه هر

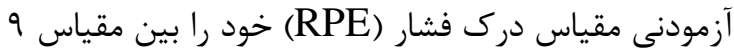
تا با آدر هر جلسه حفظ كرده است. ميزان ضربان قلب و و

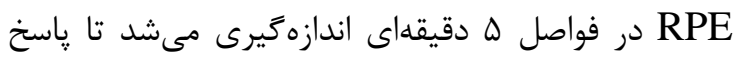

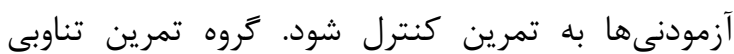

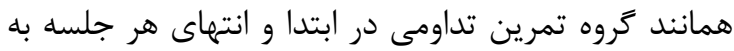

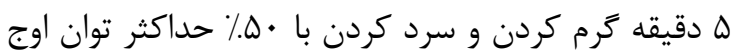
يرداخت. تمرين اصلى در اين كروه در ابتدا (هفته اول)،

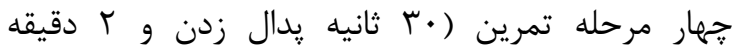

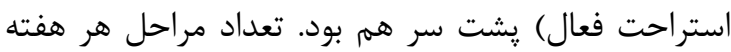

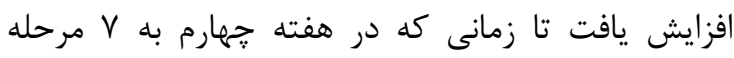
رسيد (هر هفته يك مرحله اضافه مىشد تا هفته جههارم). از هفته جهارم تا هفته آ آتعداد مراحل در همين تعداد

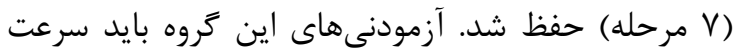

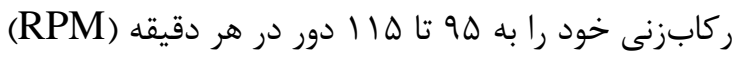




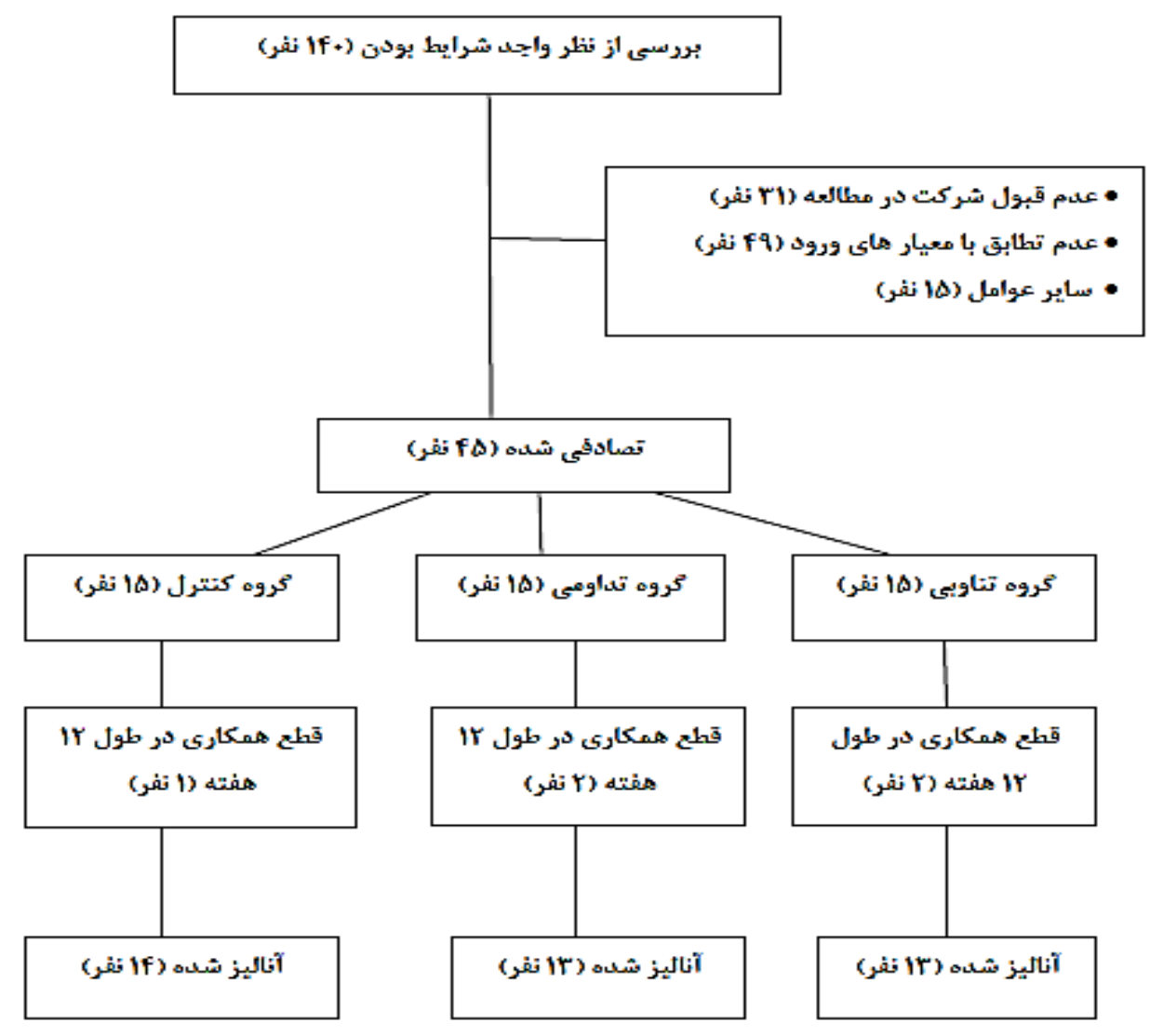

شكل ا: فلوجارت مربوط به ورود و بييَيرى آزمودنىها

نشد (ه> (P>). نتايج آزمون تحليل واريانس يكسطرفه

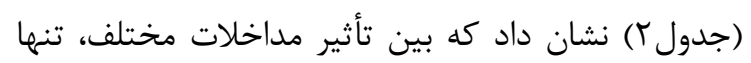

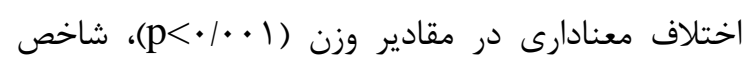
توده بدنى ( ( ) وجود دارد. اين در حالى بود كه اختلاف معنادارى بين

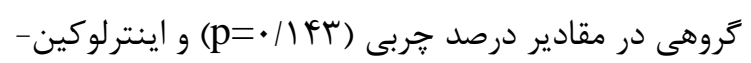

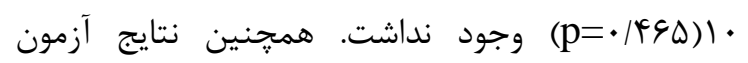

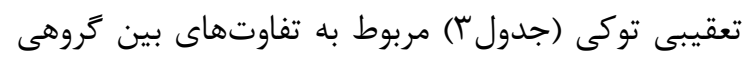

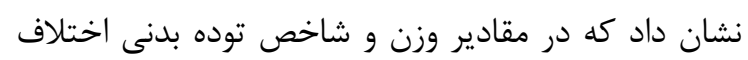

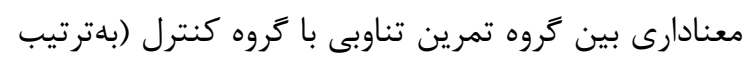

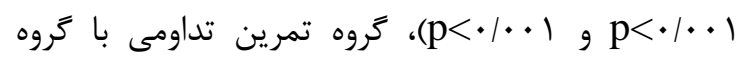

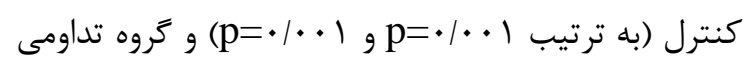

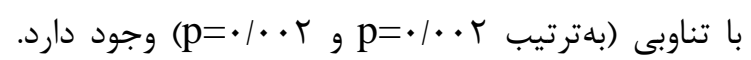

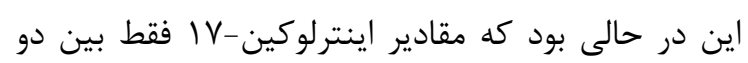

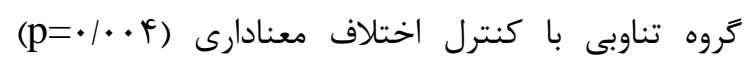
مشاهده شد.

\section{يافتهها} نتايج آزمون آمارى مربوط به ويزگگ هاى فردى آزمودنىها

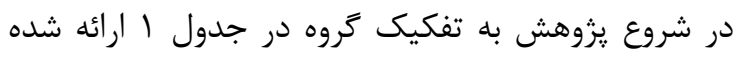
است. نتايج نشان مىدهد در در ابتداى مطالعه، بين مقادير

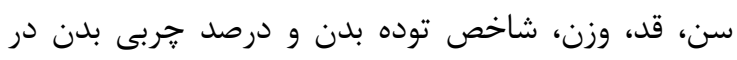

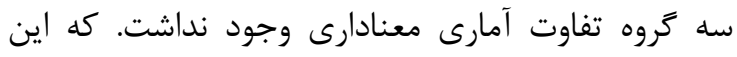

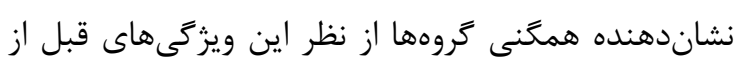
شروع يزوهش بود. نتايج آزمون تى همبسته (جدول rآ) نشان داد كه يس از

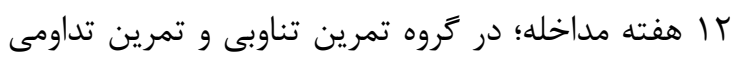

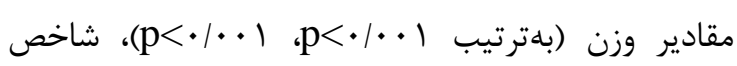

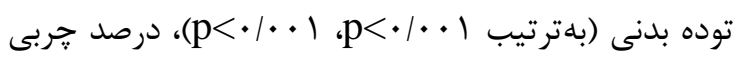

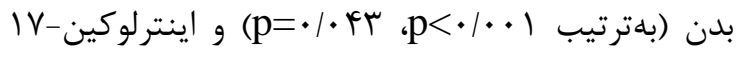

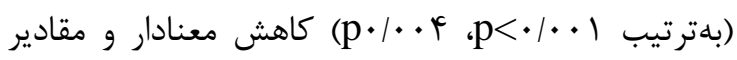

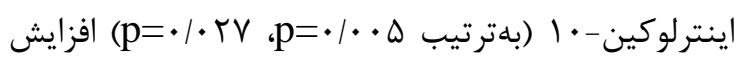

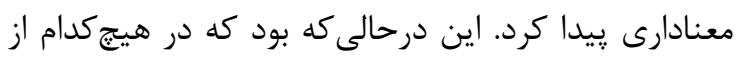
اين متغيرها در كروه كنترل اختلاف معنادارى مشاهده 


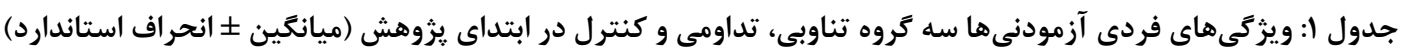

\begin{tabular}{|c|c|c|c|c|}
\hline \multirow{2}{*}{ 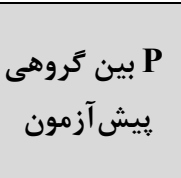 } & \multicolumn{3}{|c|}{ كروه } & \multirow[b]{2}{*}{ متغير } \\
\hline & $\begin{array}{c}\text { كنترل } \\
\text { (أ ا نفر }\end{array}$ & (זاوانفر) & (rا تناوبى ) & \\
\hline$\cdot / r \Delta F$ & $\Delta V / r \Delta \pm F / T V$ & $\Delta N / r \cdot \pm r / r r$ & $\Delta \varepsilon / \cdot V \pm r / q$. & سن (سال) \\
\hline$\cdot / r \wedge t$ & $\mid q F / Q \pm V / F F$ & $|\varepsilon| \pm V / V \Delta$ & $\mid \varepsilon r / V \& \pm F / \varepsilon$. & قد (سانتىمتر) \\
\hline$\cdot / V 9 \Lambda$ & $V F / \Delta \Delta \pm V / \cdot r$ & $V F / Y F \pm F / q \Lambda$ & $\vee \Delta / \Lambda \cdot \pm r / \Lambda q$ & وزن (كيلوَرم) \\
\hline$\cdot|4| 1$ & $r V / \varepsilon \cdot \pm I / \Lambda \Lambda$ & rN/VFE T/QF & $r \Lambda / T V \pm 1 / \Lambda$ & شاخص توده بدنى (كيلوكَم بر مترمربع) \\
\hline$\cdot / \mathrm{KH}$ & $r V / \Lambda V \pm r / 9 r$ & Fr $\pm \mathrm{V} / \cdot \varphi$ & $r q / 9 \Delta \pm r / r r$ & جربى بدن (درصد) \\
\hline
\end{tabular}

جدول r: مقايسه درونكروهى و بين كروهى متغيرهاى تركيب بدن و بيوشيميايى در سه كروه تناوبى، تداومى و كنترل

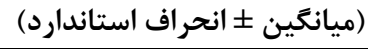

\begin{tabular}{|c|c|c|c|c|c|}
\hline Pين كروهى P & P درون كروهى P & مِ آزمون & ِيش آزمون & كروها & متغير \\
\hline \multirow{3}{*}{$<\cdot|\cdot \cdot|^{\dagger}$} & $<\cdot|\cdot \cdot|^{*}$ & $V \Psi / q 9 \pm \Delta / \cdot 1$ & $V \Delta / \Lambda \cdot \pm r / \Lambda q$ & تناوبى & \multirow{3}{*}{ وزن (كيلوكرم) } \\
\hline & $<\cdot|\cdot \cdot|^{*}$ & $V W / \mu N \pm \Delta / \cdot \Delta$ & $V F / Y F \pm F / q \Lambda$ & 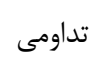 & \\
\hline & $\cdot 119$ & $V F / \Delta V \pm V / \cdot r$ & $V \Psi / \Delta \Delta \pm V / \cdot r$ & كنترل & \\
\hline \multirow{3}{*}{$<\cdot|\cdot .|^{\dagger}$} & $<\cdot|\cdot .|^{*}$ & $r V / \Delta q \pm 1 / \wedge r$ & $r N / T V \pm I / \Lambda$. & تناوبى & \multirow{3}{*}{ شاخص توده بدنى } \\
\hline & $<\cdot|\cdot \cdot|^{*}$ & $r N / F T \pm r / \cdot 1$ & $r N / V F \pm r / q F$ & 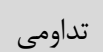 & \\
\hline & - & $T V / Q| \pm| / \Lambda \mid$ & $r V / G \cdot \pm 1 / \Lambda \Lambda$ & كنترل & \\
\hline \multirow{3}{*}{. / Fr } & $<\cdot|\cdot \cdot|^{*}$ & $r q / \cdot \varphi \pm r / r r$ & $r q / 90 \pm r / r r$ & تناوبى & \multirow{3}{*}{ جربى بدن (درصد) } \\
\hline & $\cdot / \cdot \mu^{*}$ & $F I / V Y \pm V / \cdot r$ & Fr $\pm V / \cdot G$ & 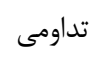 & \\
\hline & $\cdot \mid 9 \Delta \Lambda$ & $r V / A F \pm r / q \Lambda$ & $r V / A V \pm r / q r$ & كنترل & \\
\hline \multirow{3}{*}{$\cdot / \cdot \mu^{\dagger}$} & $<\cdot|\cdot \cdot|^{*}$ & $\mid \& V / \Delta \Lambda \pm r r / F \Lambda$ & $|V r / \backslash \Delta \pm r| / V q$ & ت ت ت اوبى & \multirow{3}{*}{ 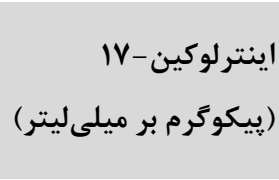 } \\
\hline & $\cdot / \cdot \varphi *$ & $|V F / T \cdot \pm| Q / \cdot r$ & $|V \varepsilon / V \Delta \pm| \Delta / \wedge F$ & 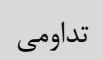 & \\
\hline & . & $|V N / F \Delta \pm r| / F$ & $I V q / \Delta \Delta \pm r \cdot / V r$ & كنترل & \\
\hline \multirow{3}{*}{.$/ 490$} & $\cdot / \cdot \Delta *$ & $r \Delta / q V \pm \Delta / F q$ & $r \Delta / r r \pm \Delta / \Delta l$ & 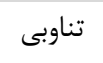 & \multirow{3}{*}{ 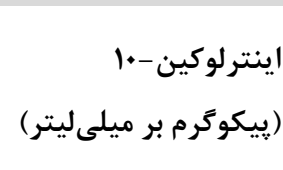 } \\
\hline & $\cdot / \cdot T V^{*}$ & $r Y / r T \pm 9 / 19$ & $r M / A F \pm 9 / T_{F}$ & 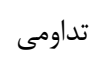 & \\
\hline & $\cdot / 4 \cdot 1$ & $r F / / \Lambda \pm 9 / r r$ & $r F / Q r \pm q / V r$ & كنترل & \\
\hline
\end{tabular}

جدول r: نتايج آزمون تعقيبى توكى مربوط به تفاوتهاى بين كروهى در متغيرهاى تركيب بدن و بيوشيميايى

\begin{tabular}{|c|c|c|c|}
\hline \multicolumn{3}{|c|}{ كروهها } & \multirow{2}{*}{ متغير } \\
\hline تناوبى -تداومى & تداومى-كنترل & تناوبى -كنترل & \\
\hline$\cdot / \cdot r *$ & $.1 . .1 *$ & $<\cdot /\left.\cdot \cdot\right|^{*}$ & وزن \\
\hline$\| \cdot r^{*}$ & $.1 . .1 *$ & $<\cdot|\cdot \cdot|^{*}$ & شاخص توده بدنى \\
\hline$\cdot 10 \cdot 1$ & $\cdot|| r \mid$ & . & جربى بدن \\
\hline $.1 .9 \mathrm{~V}$ & $\cdot / 49 \vee$ & 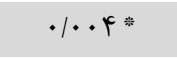 & اينترلوكين - ا \\
\hline.$/ 494$ & . $19 T T$ &.$/ 9 \Delta \Lambda$ & اينترلوكين -•1 \\
\hline
\end{tabular}

* وجود اختلاف معنادار در سطح ه+|• 
-

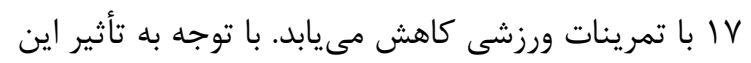
سايتوكاين در افزايش رشد سلولهاى سرطانى و متاستاز

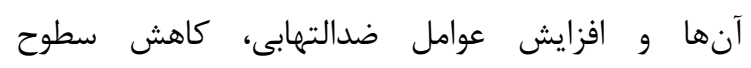

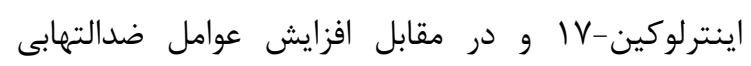

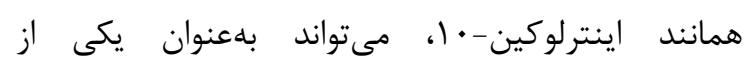

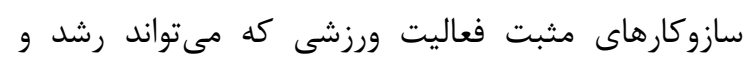

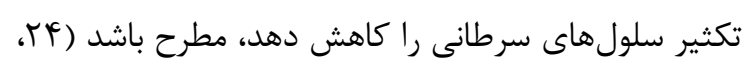

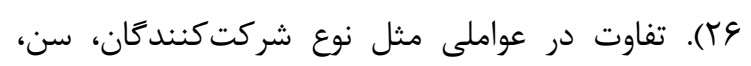

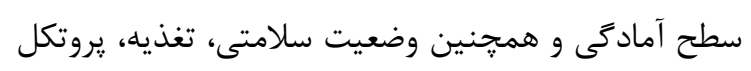

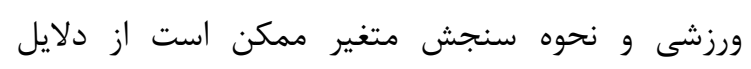

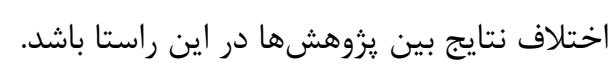

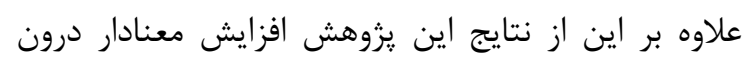

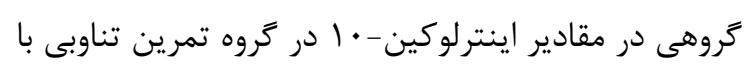

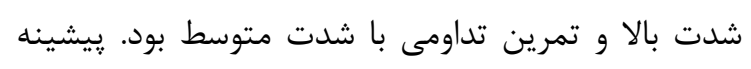

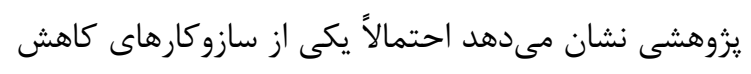

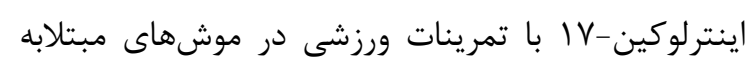

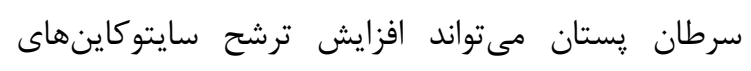

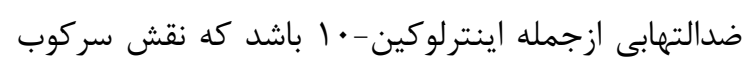

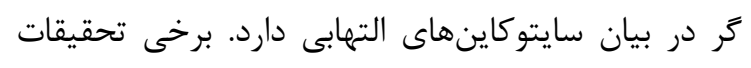

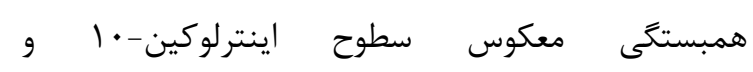

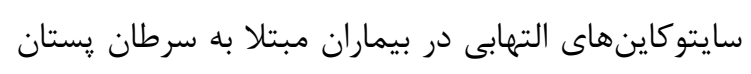

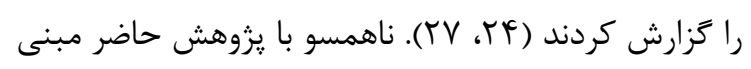

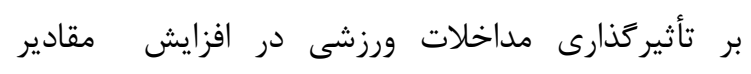

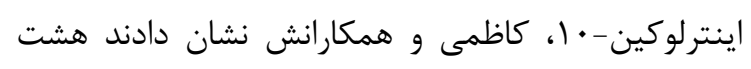

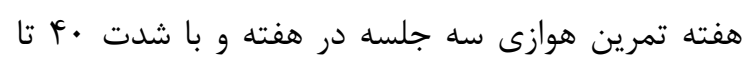

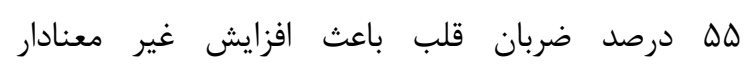

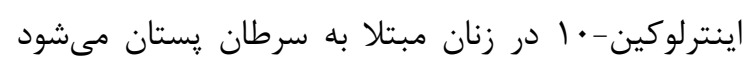

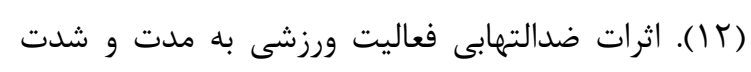

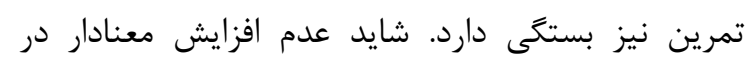

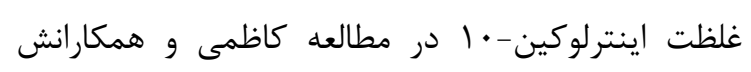

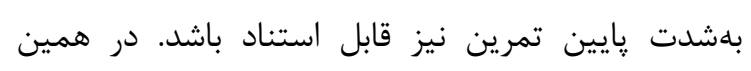

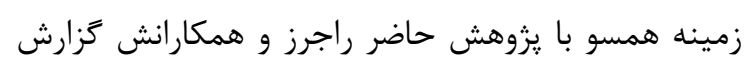
كردند كه سه ماه فعاليت ورزشى منجر به افزايش ماند معنادار

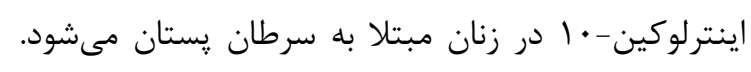
تمرينهاى ورزشى مىتوانند از راه تنظيم و تعديل تعادل

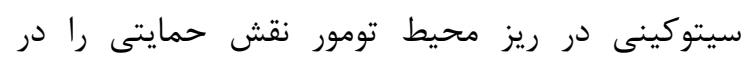

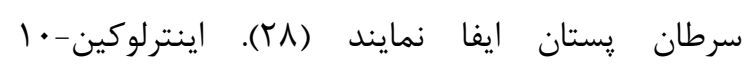
سايتوكاين ضدالتهابى و ضد رگزايى تومور است كه نقش إنش

\section{بحث}

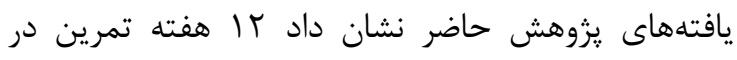

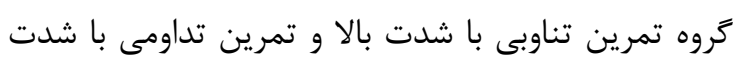

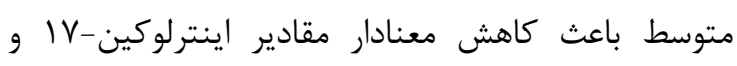

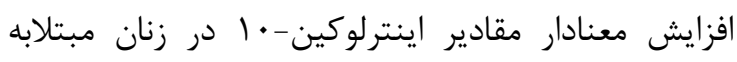

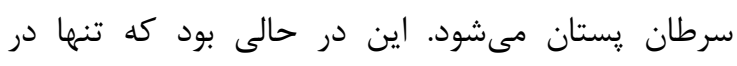

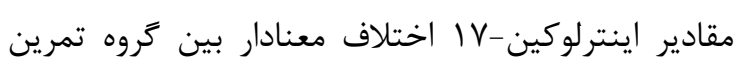
تناوبى و كنترل مشاهده شد. علاوه بر اين بين دو شيوه

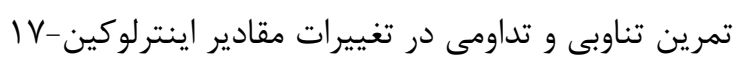

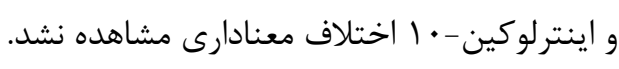
در يزوهش حاضر تمرين تناوبى با شدت بالا و تمرين تداومى با شدت متوسط باعث كاهش ماضر معنادار مقادير

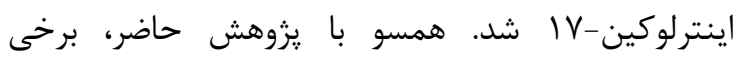

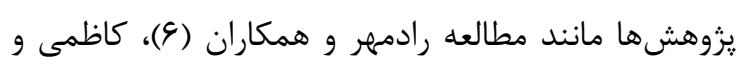

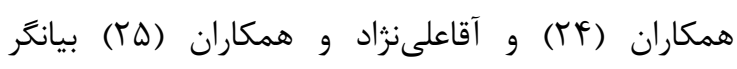

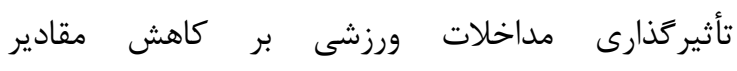

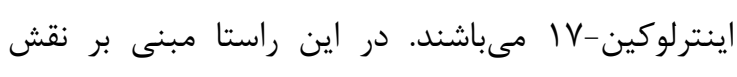

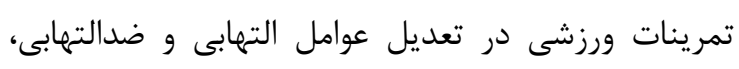

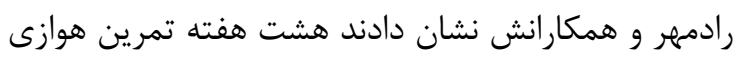

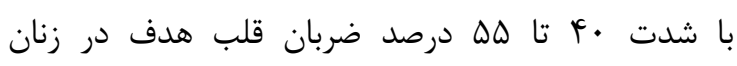

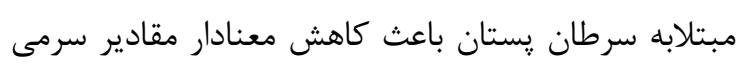

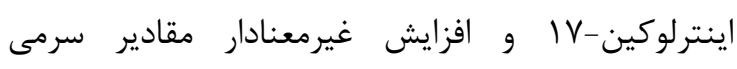

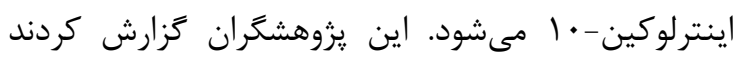

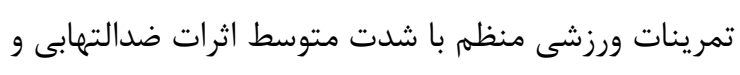

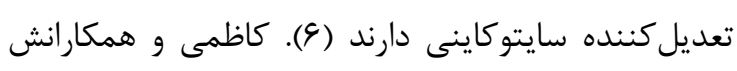

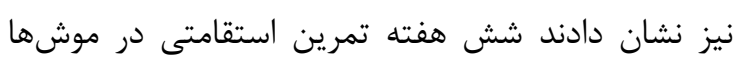

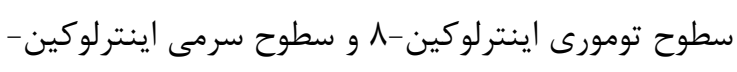

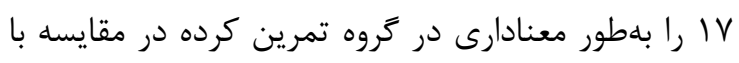

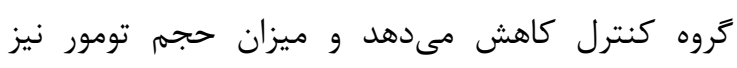

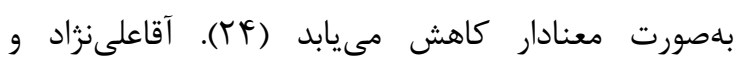

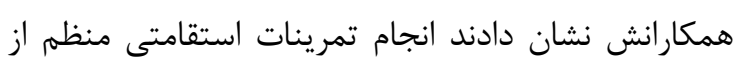

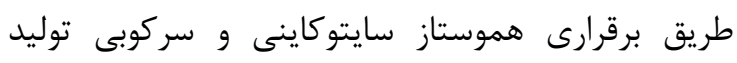

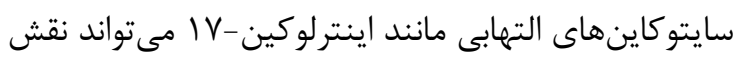

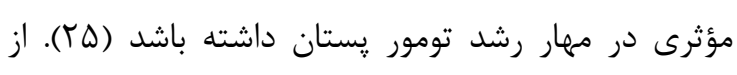

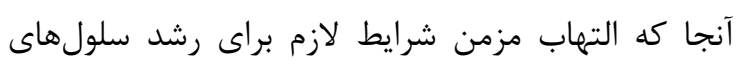

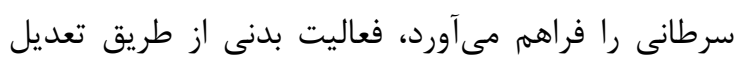

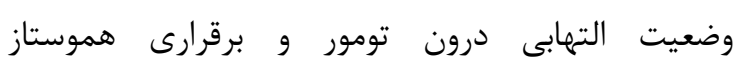

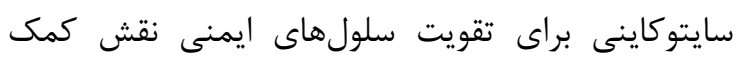

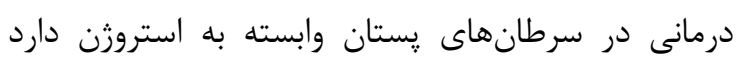


اينترلوكين-IV و اينترلوكين-• إ بود. به علت محدود بود

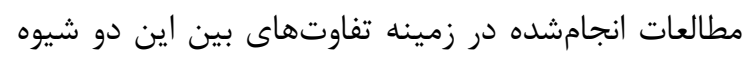

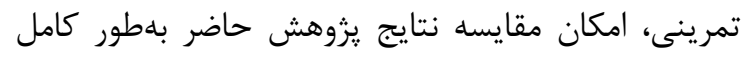

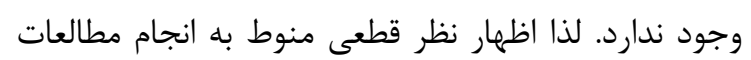

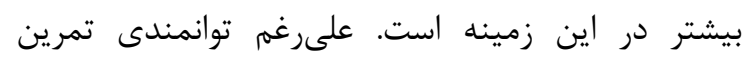

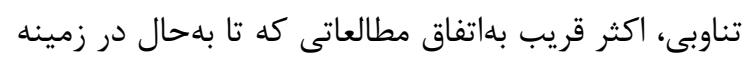

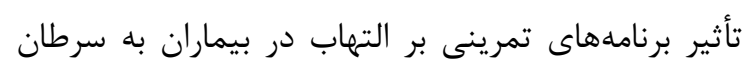

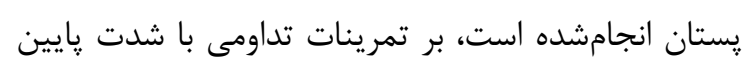

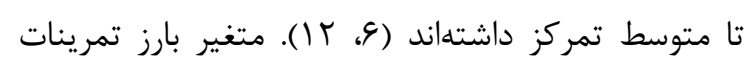

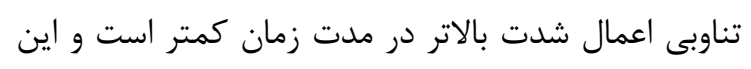

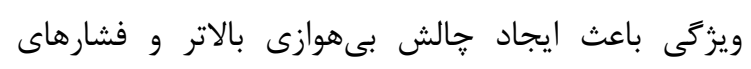
بيشتر نسبت به تمرينات تداومى در تمام سيست سيتمهادي

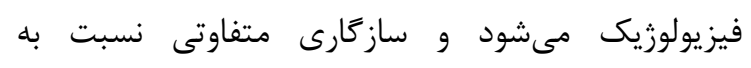

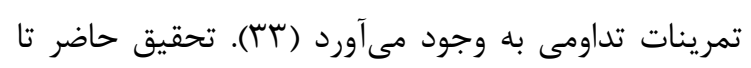

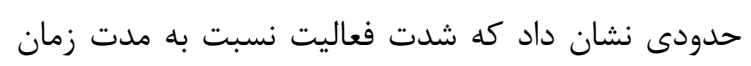

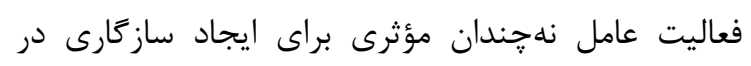

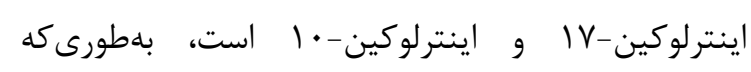

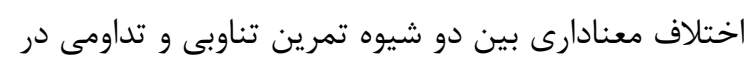

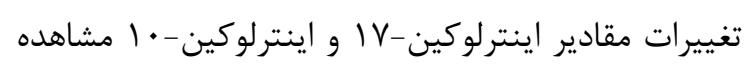

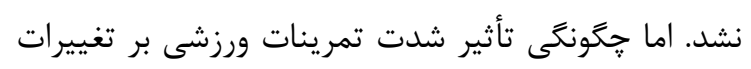

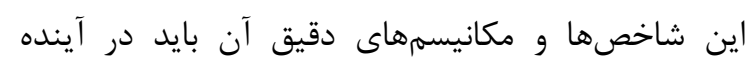

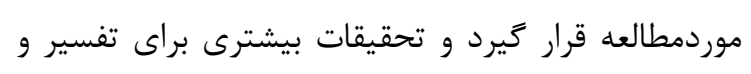

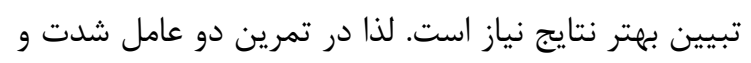

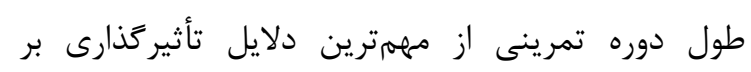

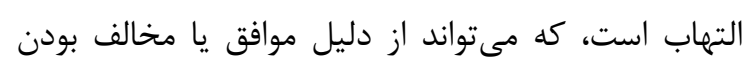

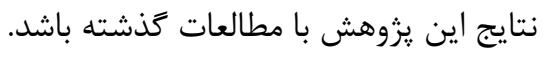

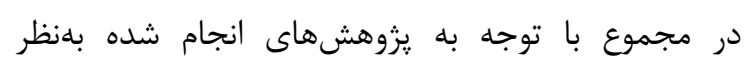

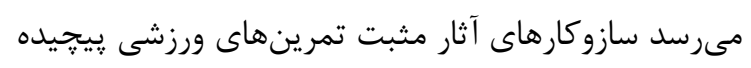

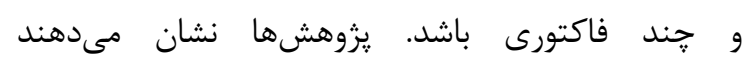
تمرينهاى ورزشى در ايجاد هموستاز سلولى و وتونى توليد

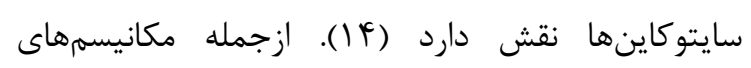

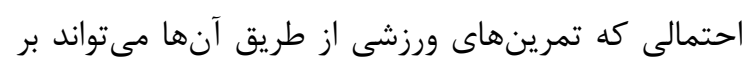

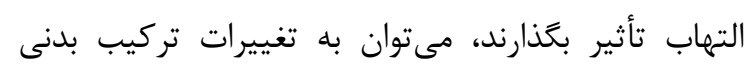

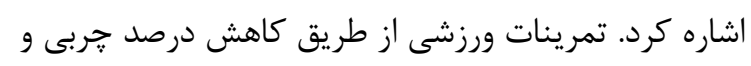

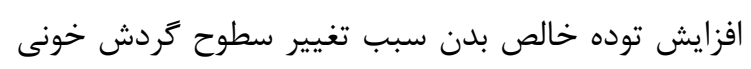

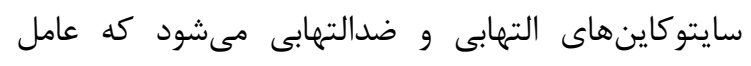

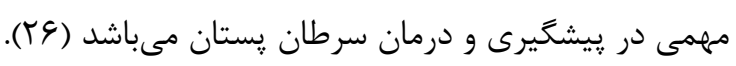
يزوهشكران با بررسى سازوكارهاى مختلف دركير در در تعامل دئل

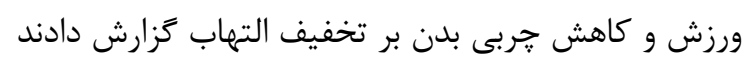

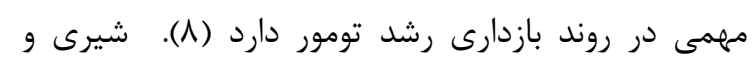

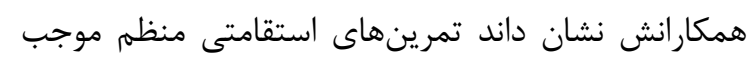

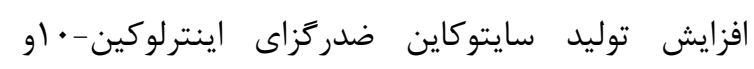

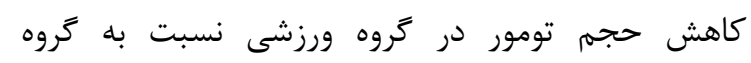

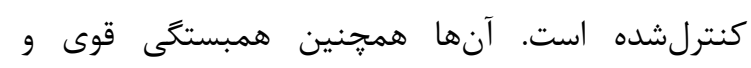
معكوسى بين اين سيتوكين با كاهش حجم تومور مشاهده

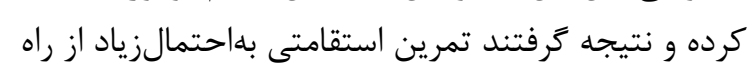

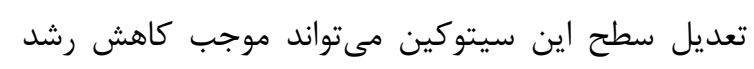

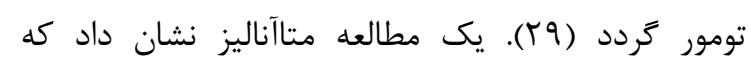

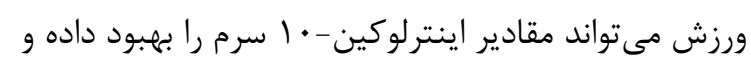

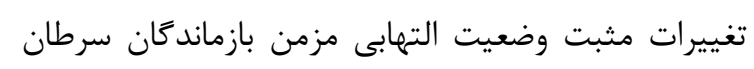

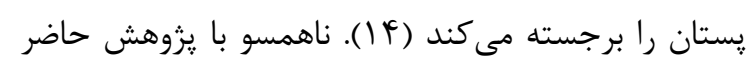

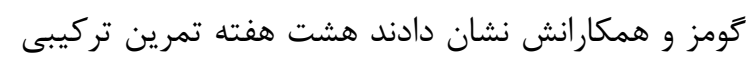

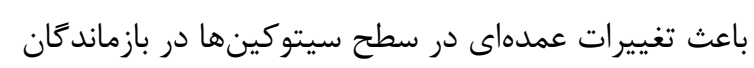

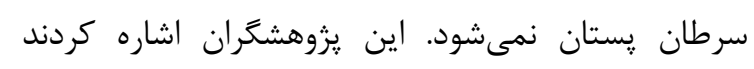

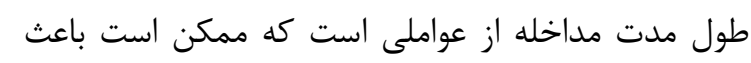
عدم تغيير مقادير سايتوكاينها شده است (••آ). از دلايل

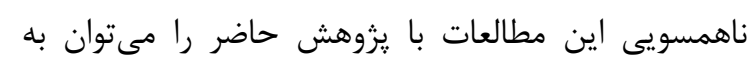

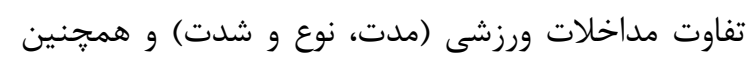

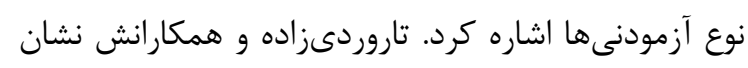

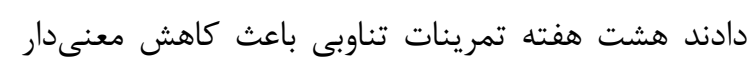

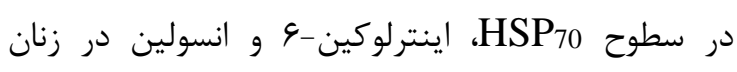

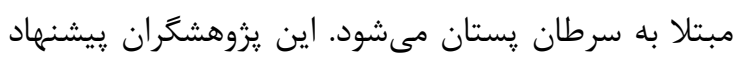

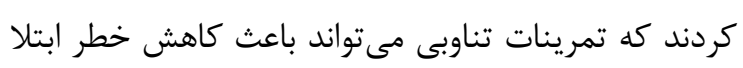

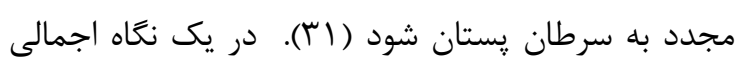

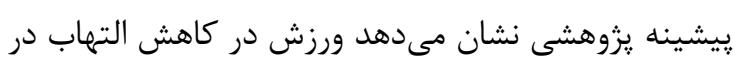

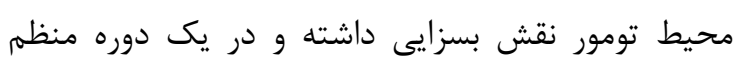

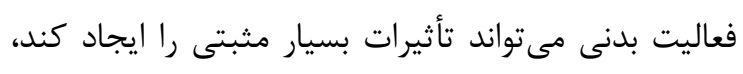

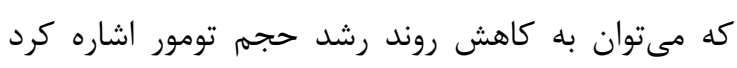
(IF) كاهش التهاب رشد تومور نيز كاهش بلهزئ بايى خواهد

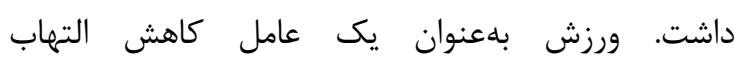
شناختهشده و نيز در كاهش حجم تومور نيز مؤثر است

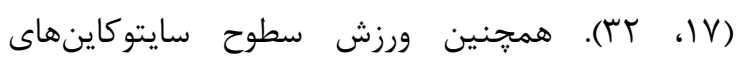

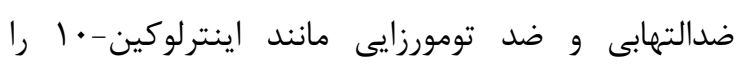

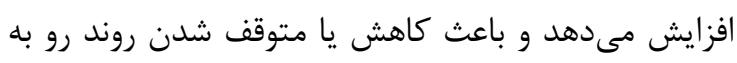

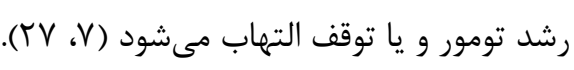

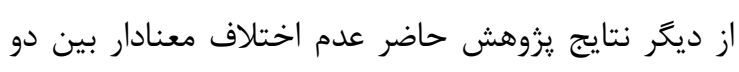

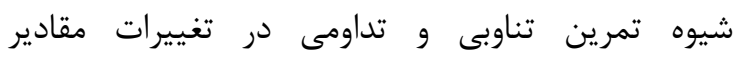




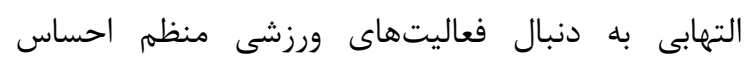
مىشود. از اين رو يِيشنهاد مىشود در مطالعات آينده اثر آثرات

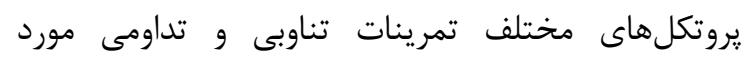
بر برونى قرار كيرد.

\section{نتيجه "نيرى}

بلهور خلاصه، يافتهاى تحقيق حاضر حاكى از تأثير

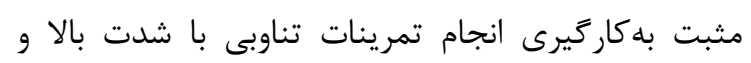

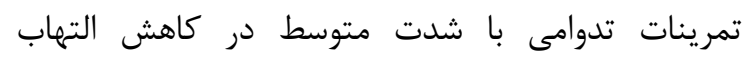

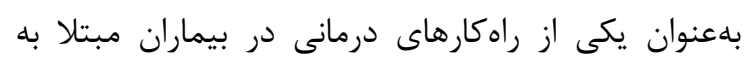

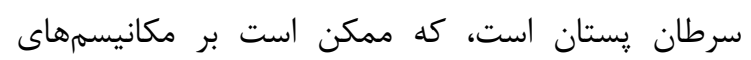

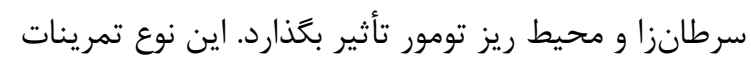

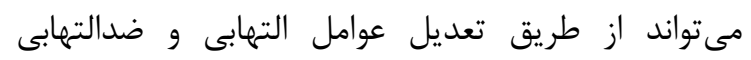

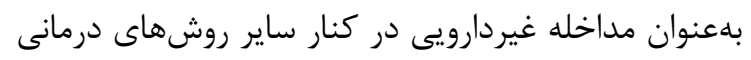

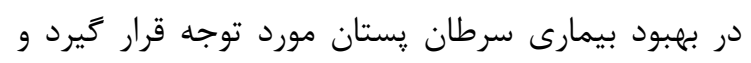
مناسب بودن نسخه تجويز ورزش در اين جمعيت را تقويت بردي

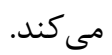

\section{تشكر و قدردانى}

از زحمات و مساعدت كليه آزمودنىهاى تحقيق حاضر كه وله

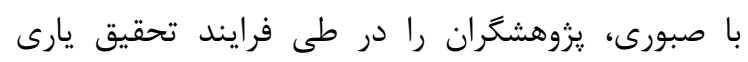

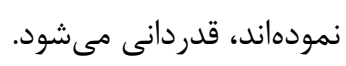

\section{تعارض منافع}

نويسندًان اعلام مىدارند كه هيجَّّنه تعارض منافعى در

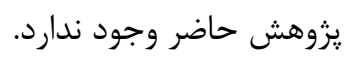

كه فعاليت بدنى با تأثير بر جربى بدن نيز موجب كاهش

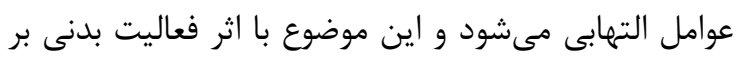

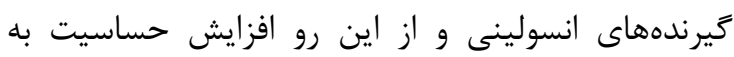

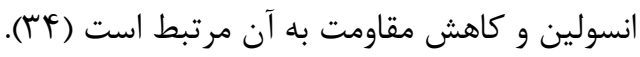

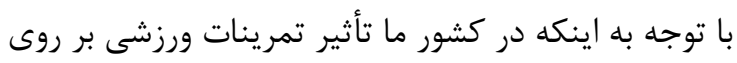

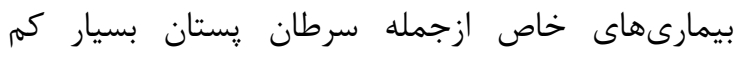

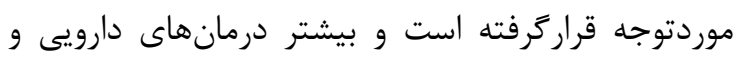

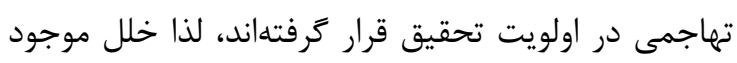

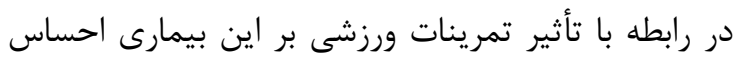

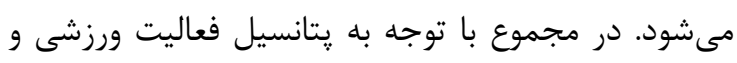

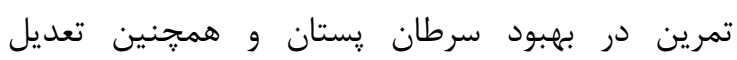

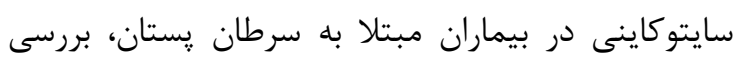
سازوكارهاى سلولى و مولكولى مؤثر فعاليت و تمرينات دئي

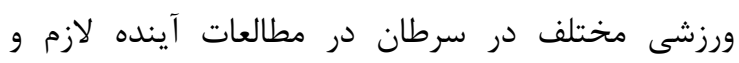

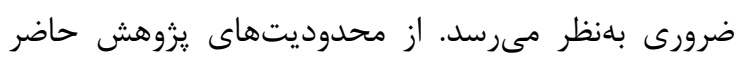
مىتوان به عدم كنترل كامل رزيم غذايى آزمودنىها،

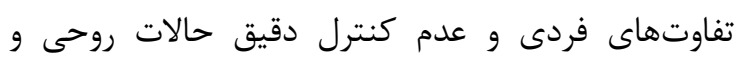

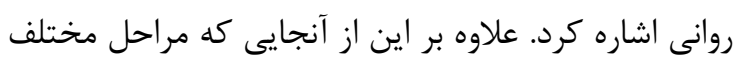

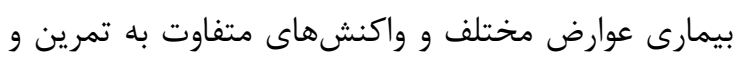

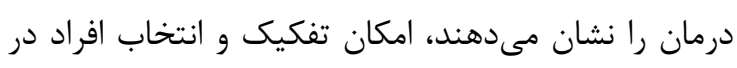

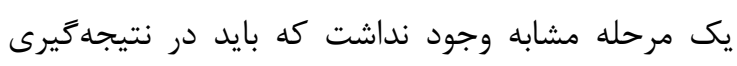

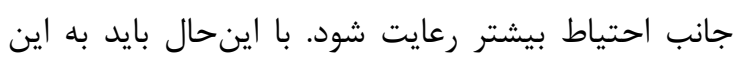

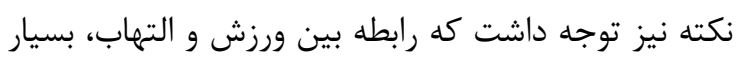

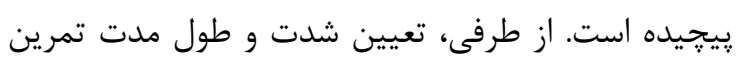
عاملى مهمى در به حداكثر رساندن آثار اين تمرينات بوده

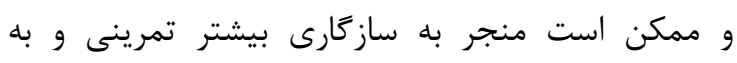

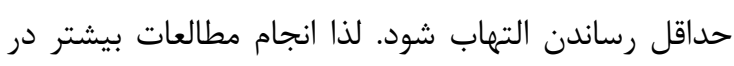

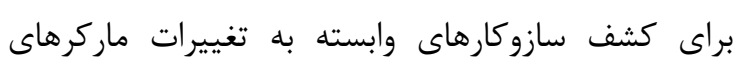

high risk or advanced breast cancer: an update and expectation. Curr. Cancer Drug Targets. 2009; 9:888-903.

4. Korkaya H, Liu S, Wicha MS. Breast cancer stem cells, cytokine networks, and the tumor microenvironment. J Clin Invest 2011; 121: 3804-9. 
5. Kawaguchi M, Adachi M, Oda N, Kokubu F, Huang S-K. IL-17 cytokine family. Journal of Allergy and Clinical Immunology. 2004; 114(6): 1265-73.

6. Radmehr L, Kalantari-Khandan B, Kazemi A. The effect of 8 weeks of endurance training on serum levels of IL-10 and IL-17 in elderly women with breast cancer. Journal of Shahed University.2016; 23(1):39-46.

7. Liu J, Duan Y, Cheng X, Chen X, Xie W, Long $\mathrm{H}$, et al. IL-17 is associated with poor prognosis and promotes angiogenesis via stimulating VEGF production of cancer cells in colorectal carcinoma. Journal of Biochemical and biophysical research communications. 2011; 407:348-54.

8. Hamidullah KH, Changkija B, Konwar R. Role of interleukin-10 in breast cancer. Breast Cancer Research and Treatment. 2012; 133: 11-21.

9. Candido J, Hagemann T. Cancer-related inflammation. Journal of clinical immunology. 2013; 33:79-84.

10. Langsenlehner U, Krippl P, Renner W, Yazdani-Biuki B, Eder T, Koppel H, et al. Interleukin-10 promoter polymorphism is associated with decreased breast cancer risk. Breast cancer research and treatment. 2005; 90(2):113-5.

11. Laird BJ, Scott AC, Colvin LA, McKeon AL, Murray GD, Fearon KC, et al. Cancer pain and its relationship to systemic inflammation: an exploratory study. Pain. 2011; 152(2):4603.

12. Kazemi AR, Kalantari Khandani B, AshrafGanjoie A. the effect of 8 weeks endurance training on serum levels of Il-10 and Il-8, and white blood cell count in women with breast cancer. Journal of Fasa University of Medical Sciences. 2016; 6(2):194-201.

13. Dieli-Conwright CM, Orozco BZ. Exercise after breast cancer treatment: current perspectives. Breast Cancer (Dove Med Press). 2015; 21(7):353-62.

14. Jose F. Meneses-Echávez, Jorge E. CorreaBautista, Emilio González-Jiménez, et al. the effect of exercise training on mediators of inflammation in breast cancer survivors: a systematic review with meta-analysis. Cancer Epidemiol Biomarkers Prev. 2016; 25:100917.

15. Schubert C, Hong S, Natarajan L, Mills PJ, Dimsdale JE. The association between fatigue and inflammatory marker levels in cancer patients: a quantitative review. Brain Behav Immun. 2007; 21:413-27.

16. Lee BN, Dantzer R, Langley KE, Bennett GJ, Dougherty PM, Dunn AJ, et al.
A cytokine-based neuroimmunologic mechanism of cancer-related symptoms. Neuroimmunomodulation. 2004; 11:279-92.

17. Zielinski MR, Muenchow M, Wallig MA, Horn PL, Woods JA. Exercise delays allogeneic tumor growth and reduces intratumoral inflammation and vascularization. J Appl Physiol (1985). 2004; 96: 2249-56.

18. Murphy EA, Davis JM, Barrilleaux TL, McClellan JL, Steiner JL, Carmichael MD, et al. Benefits of exercise training on breast cancer progression and inflammation in C3(1) SV40Tag mice. Cytokine. 2011; 55:274-9.

19. Rakobowchuk M, Tanguay S, Burgomaster KA, Howarth KR, Gibala MJ, MacDonald MJ. Sprint interval and traditional endurance training induce similar improvements in peripheral arterial stiffness and flow-mediated dilation in healthy humans. American Journal of Physiology-Regulatory, Integrative and Comparative Physiology. 2008; 295(1):R236R42.

20. Gibala MJ, Little JP, MacDonald MJ, Hawley JA. Physiological adaptations to low-volume, high-intensity interval training in health and disease. The Journal of physiology. 2012; 590(5):1077-84.

21. Medicine ACoS. ACSM's guidelines for exercise testing and prescription: Lippincott Williams \& Wilkins. 2014; 1-186

22. Irwin ML, American College of Sports Medicine. ACSM's guide to exercise and cancer survivorship.Champaign, IL: Human Kinetics. 2012; 1-100.

23. Northey JM, Pumpa KL, Quinlan C, Ikin A, Toohey K, Smee DJ, Rattray B2.Cognition in breast cancer survivors: A pilot study of interval and continuous exercise. J Sci Med Sport. 2019; 22(5):580-5.

24. Kazemi AR, Agha Alinejad H, Rasul Eslami, Ehsan P, Baghaie R, Dabaghzadeh R, Ghanbarzadeh $M$. investigating the effect of endurance training on tumor level of Il-8 and serum level of Il-17 in female mice with breast cancer. Journal of Fasa University of Medical Sciences. 2015; 5(3):347-55.

25. Agha-Alinejad H, Saei MA. Mahdavi M. Amani S, et al. The effect of 6 weeks endurance training on the levels of some cytokines in tumor microenvironment in breast cancer bearing mice. Journal of Sport Biosciences. 2015; 6(4):483-96.

26. Kazemi A, Radmehr L, Ghanbarzadeh M. the effect of 8 weeks of aerobic training on serum levels of interleukin-17, adiponectin, and estradiol in women with breast cancer. J Isfahan Med Sch. 2016; 33(364):2263-9. 
27. Li Y, Yu H, Jiao S, Yang J. Prognostic value of IL-10 expression in tumor tissues of breast cancer patients. Chinese journal of cellular and molecular immunology. 2014; 30(5):51720.

28. Rogers LQ, Fogleman A, Trammell R, Hopkins-Price P, Vicari S, Rao K, et al. Effects of a physical activity behavior change intervention on inflammation and related health outcomes in breast cancer survivors: pilot randomized trial. Integr Cancer Ther. 2013; 12(4):323-35.

29. Shiri Y, Agha-Alinejad H, Gharakhanlou R, Amani shalamzari S, Saei MA. effect of six weeks endurance training on tumor tissue Il10 cytokine levels in breast cancer bearing mice. Iranian Journal of Endocrinology and Metabolism.2014; 16(3):205-10.

30. Gomez AM, Martinez C, Fiuza-Luces C, Herrero F, Perez M, Madero L, Ruiz JR, Lucia A, Ramirez M. exercise training and cytokines in breast cancer survivors. Int $\mathbf{J}$ Sports Med 2011; 32:461-7.
31. Tarverdizadeh B, Bedrous M. The Effect of Interval Training on HSP70 and Some Inflammatory, Growth and Functional Markers among Women with Breast Cancer .IJOGI. 2016; 16(37):16-24.

32. Moylan S, Eyre H, Maes M, Baune BT, Jacka F, Berk M. Exercising the worry away: how inflammation, oxidative and nitrogen stress mediates the beneficial effect of physical activity on anxiety disorder symptoms and behaviours. Neuroscience \& Biobehavioral Reviews. 2013; 37(4):573-84.

33. Azevedo L, Dos Santos M. High-intensity intermittent exercise training for cardiovascular disease. Journal of Novel Physiotherapies. 2014; 4:1-8.

34. Wang M, Dhingra K, Hittelman WN, Liehr JG. Lipid peroxidation-induced putative malondialdehyde-DNA adducts in human breast tissues. Cancer Epidemiol Biomarkers Prev. 1996; 5:705-10. 